\title{
Pelatihan Penyusunan Instrumen Penilaian Ranah Psikomotor (Keterampilan) Bagi Guru-Guru Fisika SMA/MA di Yogyakarta
}

\section{Training of Develoment of Psychomotoric Assessment Instrument in Physics Subject for Physics Teachers of Senior High School in Yogyakarta}

\author{
Edi Istiyono*, Suyoso, Nur Kadarisman
}

Jurusan Pendidikan Fisika, FMIPA, UNY, *Email: edi_istiyono@uny.ac.id

\begin{abstract}
Abstrak
Pengabdian pada Masyarakat (PPM) ini bertujuan: (a) Setelah mengikuti kegiatan ini, para peserta diharapkan menjadi lebih terampil dalam menyusun instrumen penilaian keterampilan dengan pengamatan dan tes, dan (b) Setelah mengikuti kegiatan ini, para peserta diharapkan lebih terampil dalam menyususn pedoman penskoran/rubrik penilaian keterampilan. PPM ini berupa pelatihan yang dilakukan dalam bentuk klasikal. Metode yang diterapkan adalah ceramah, diskusi-informasi, dan workshop. Langkah-langkah Kegiatan: (a) Orientasi kondisi kelompok sasaran, (b) Orientasi untuk menentukan kebutuhan, (c) Penentuan jadwal dan tempat pelaksanaan, (d) Pelaksanaan kegiatan, (e) Observasi/Refleksi, (f) Evaluasi, dan (g) Penyusunan. Khalayak Sasaran kegiatan pelatihan ini adalah semua guru-guru Fisika di Yogyakarta. Berdasarkan pengamatan pelaksanaan PPM dapat disimpulkan: (a) Peserta pelatihan guru-guru Fisika SMA di DIY meningkat keterampilan dalam memilih dan menyusun instrumen penilaian keterampilan dengan pengamatan dan tes, dan (b) Peserta pelatihan guru-guru Fisika SMA di DIY meningkat keterampilan dalam menyusun pedoman penskoran.
\end{abstract}

Kata kunci: pelatihan, instrumen penilaian keterampilan, fisika

\section{Abstract}

Community Services aims: after doing this activity: (a) the participants were expected to become more skilled in selecting and preparing psychomotoric assessment instruments and $(b)$ participants were expected to be skilled in drawing up the scoring guidelines. Community Services is training model done in the classical modforl. The method applied is the lecture, discussioninformation, and workshops. Description of Activities: (a) The orientation of the target group conditions, (b) Orientation to determine needs, (c) Determination of schedule and place of execution, (d) Implementation of activities, (e) Observation / Reflection, $(f)$ Evaluation, and ( $g$ ) Preparation. Target participant of this training is all senior high physics teachers in Yogyakarta. Based on the observation of the implementation of the training can be concluded: (a) the senior high science teacher trainees in Yogyakarta increased skills in selecting and preparing psychomotoric assessment instruments and (b) Participants, the senior high school physics teachers in Yogyakarta increase skill in developing scoring guidelines.

Key words: training, psychomotoric assessment instruments, physiscs

\section{PENDAHULUAN}

Pendidikan yang baik tentunya menyesuaikan dengan perkembangan zaman. Berkaitan dengan hal tersebut, agar pendidikan dapat mengimbangi kemajuan zaman, maka pemerintah sebagai pemegang kebijakan pendidikan nasional melakukan merevisi kurikulum secara periodik 10 tahunan. Di dalam kurikulum di samping memuat materi yang harus disampaikan, tetapi juga strategi, pendekatan maupun metode yang diterapkan dalam pembelajaran.

Berkaitan dengan pengembangan kurikulum, 
pengembangan kurikulum yang dianut oleh negara-negara yakni: (a) pendekatan materi (content-based approach), (b) pendekatan kompetensi/ kemampuan dasar (competenceloutcome-based approach), dan (c) pendekatan kombinasi (Sukardi, 2002). Negara yang masih menganut kurikulum berbasis materi (contain) sudah sangat sedikit. Dari yang sangat sedikit tersebut termasuk jepang dan Indonesia. Jika diamati trend di berbagai belahan dunia pendekatan dalam pengembangan kurikulum beralih ke pendekatan kompetensi atau kombinasi. Untuk itulah Indonesia telah menterapkan kurikulum berbasis kompetensi (KBK) 2004 dan 2006 menjadi Kurikulum Tingkat Satuan Penidikan (KTSP), akhirnya di tahun 2013 menjadi Kurikulum 2013.

Pada kurikulum 2013, kemamuan peserta didik terdiri atas tiga ranah, yakni: sikap, pengetahuan, dan keterampilan. Untuk memantau proses, kemajuan, dan perbaikan hasil belajar peserta didik secara berkesinambungan, diperlukan penilaian. Penilaian pendidikan adalah proses pengumpulan dan pengolahan informasi untuk menentukan pencapaian hasil belajar peserta didik (Peraturan Menteri Pendidikan Nasional No 20, 2007). Penilaian keterampilan dapat dilakukan dengan pengamatan dan tes. Penilaian keterampilan memang yang paling baik dengan pengamatan. Namun perlu dingat bahwa penilaian dengan pengamtan memerlukan banyak waktu dan pengamatan, oleh karena itu dapat pula dilakukan dengan tes.

Dalam pembelajaran Fisika, peserta didik untuk terlibat secara fisika maupun mental. Pemberian pengalaman secara langsung pada peserta didik dalam pembelajaran Fisika sangat penting, untuk mengembangkan kompetensi, sehingga peserta didik dapat bereksplorasi dan memahami alam sekitar secara ilmiah dengan lebih mendalam.

Untuk meningkatkan kualitas

pembelajaran dapat dimulai dengan menyusun tujuan pembelajaran yang tepat. Salah satu tujuan Mata Pelajaran Fisika adalah agar peserta didik memiliki kemampuan mengembangkan kemampuan bernalar dalam berpikir analisis induktif dan deduktif dengan menggunakan konsep dan prinsip fisika untuk menjelaskan berbagai peristiwa alam dan menyelesaian masalah baik secara kualitatif maupun kuantitatif (BSNP, 2013: 160). Hal ini diperkuat dengan anjuran pemerintah dalam kurikulum tingkat satuan pendidikan. Penilaian (asesmen) hendaknya direncanakan untuk mengukur pengetahuan dan konsep, keterampilan proses sains (KPS), dan penalaran tingkat tinggi (Pusat Kurikulum Diknas, 2013: 23-24). Dengan demikian, melalui pembelajaran fisika dan penilainnya diharapkan peserta didik dapat mengembangkan diri dalam berpikir. Peserta didik dituntut tidak hanya memiliki kemampuan berpikir tingkat rendah (lower order thinking skills), tetapi sampai pada kemampuan berpikir tingkat tinggi (higher order thinking skills, HOTS).

Penilaian (asesmen) hendaknya: (1) direncanakan untuk mengukur pengetahuan dan konsep, keterampilan proses sains (KPS), dan penalaran tingkat tinggi; (2) mengadopsi bentuk tipe soal serupa dengan PISA dan TIMSS untuk mendorong proses belajar mengajar (PBM) untuk berkontribusi pada peningkatan literasi sains peserta didik dan sekaligus menggali kemampuan berpikir ilmiah, kritis, kreatif, dan inovatif; (3) menekankan penguasaan konsep tingkat rendah dan tinggi dengan variasi bentuk penilaian (pilihan ganda, pilihan ganda beralasan, uraian terbatas); dan (4) memperkenalkan tipe soal yang diujikan secara nasional maupun internasioanl (Pusat Kurikulum Diknas, 2013:23-24). Dengan demikian, ada amanah penting dalam penilaian, yakni: (1) sangat diperlukan penilaian yang tidak hanya mengukur pengetahuan, tetapi juga mengukur sikap dan keterampilan dan (2) menggunakan variasi tipe soal yang tidak hanya pilihan ganda dan uraian, namun perlu adanya modifikasi yakni: pilihan ganda beralasan kepada peserta didik dan guru IPA. Oleh karena diperlukan instrumen untuk mengukur keterampilan. Teknik 
penilaian keterampilan ini terdiri atas: observasi dan tes. Dengan demikian perlu dikembangkan isntrumen berupa lembar pengamatan dan butir-butir tes.

Berdasarkan informasi dari guruguru Fisika SMA di Yogyakarta, sebagian besar di sekolah, belum optimal pelaksanaan penilaian keterampilan dengan pengamatan. Bahkan, masih jarang yang melakukan penilaian keterampilan dengan tes.

Dari uraian di atas, berarti bahwa masih kurang adanya instrumen penilaian keterampilan Fisika. Dengan demikian perlu kiranya diadakan suatu pelatihan penyusunan instrumen penilaian keterampilan baik berupa lembar pengamatan atau tes.

\section{SOLUSI/TEKNOLOGI}

Kegiatan pelatihan ini meliputi ceramah, diskusi-informasi, dan workshop. Secara rinci metode yang digunakan dapat diuraikan sebagai berikut:

Pelatihan penyusunan instrumen
penilaian pembelajaran Fisika.

b. Diskusi-informasi tentang berbagai konsep Fisika yang harus disampaikan kepada peserta didik. Selanjutnya perancangan instrumen penilaian keterampilan yang sesuai dengan konsep Fisika yang diajarkan.

Evaluasi kegiatan pengabdian kepada masyarakat ini meliputi lima hal, yakni:

a. Penilaian kemampuan peserta dalam menyusun instrumen penilaian keterampilan dalam pembelajaran Fisika.

b. Evaluasi pelaksanaan pelatihan ini.

\section{HASIL DAN DISKUSI}

\section{Hasil Kegiatan}

Kegiatan PPM ini dilakukan dalam 2 pertemuan, yakni tanggal 1 dan 8 September 2016. Di samping itu tugas mandiri selama 6 hari (2 sampai dengan 7 September 2016). Kegiatan PPM tersebut dilaksanakan di
Laboratorium Fisika Dasar Jurdik Fisika FMIPA Universitas Negeri Yogyakarta. Pelaksana PPM oleh tiga dosen dan dibantu satu orang mahasiswa. Peserta kegiatan ini terdiri dari guru-guru Fisika SMA/MA Daerah Istimewa Yogyakarta sebanyak 25 orang.

\section{Pertemuan ke-1 (1 September 2016)}

Pertemuan tanggal 1 September 2016 ini merupakan pertemuan awal, beberapa materi kegiatan pada pertemuan pertama ini adalah:

a. Penyampaian pengantar umum oleh Dr.

Edi Istiyono, M.Si. selaku Ketua Pelaksana PPM (pengertian, maksud, dan tujuan dilaksanakan kegiatan PPM )

b. Penyampaian makalah I oleh: Suyoso, M.Si. (judul: Penyusunan Kit Alat Fluida Bergerak)

c. Penyampaian makalah II oleh: Dr. Edi Istiyono, M.Si. (judul: Konstruksi Instrumen Psikomotor )

Di akhir pertemuan setiap peserta mengajukan $\mathrm{KD}$ yang akan disusun instrumen penilaiannya. Selanjutnya penyusunan instrumen dilakukan secara mandiri.

\section{Pertemuan ke-2 (8 September 2016)}

Pertemuan tanggal 8 September 2016 ini melaksanakan beberapa kegiatan antara lain:

a. Diskusi hasil penyusuanan instrumen penilaian keterampilan dengan pengamatan dan tes oleh peserta PPM dan klarifikasinya.

b. Perbaikan dan penyempurnaan instrumen penilaian keterampilan dengan pengamatan dan tes pada Pembelajaran Fisika SMA/MA.

c. Tanggapan dan masukan dari peserta pelatihan terhadap kegiatan yang diselenggarakan.

\section{Pembahasan}

Berdasarkan pengamatan selama kegiatan PPM berlangsung, diketahui bahwa:

a. Sebagian guru peserta pelatihan belum menguasai pembelajaran Fisika sesuai dengan Kurikulum Nasional (Kurikulum 2013 yang direvisi) 
b. Sebagian besar guru masih kesulitan menyusun instrumen penilaian keterampilan dengan pengamatan dan tes dalam pembelajaran Fisika SMA/MA.

Keadaan di atas disebabkan oleh beberapa hal, antara lain:

a. Belum semua guru Fisika SMA menguasai seluk beluk pembelajarn Fisika sesuai dengan kurikulum 2013 yang telah direvisi.

b. Banyaknya jam pelajaran guru minimal 24 jam per minggu, sehingga guru kurang dalam melakukan persiapan pembelajaran.

c. Banyaknya ragam penilaian dalam kurikulum 2013, sehingga guru tidak menguasai instrumen penilaian secara mendalam.

Keadaan tersebut di atas jika tidak tanggulangi atau paling tidak dikurangi jelas akan menghambat pelaksanaan kurikulum 2013 yang sudah mulai diterapkan tahun 2014 dan yang sekarang telah dilakukan revisi. Hal ini mengingat dalam kurikulum tersebut menuntut guru terampil sebagai fasilitator dalam pelaksanaan pembelajaran yang juga harus melakukan penilaian otentik.

Di samping tersebut di atas, sebagian guru belum paham kurikulum 2013 yang mulai diterapkan dengan persiapan yang kurang memadahi. Dengan begitu jelas masih banyak guru yang belum siap melaksanakan kurikulum 2013. Ditambah lagi, tahun ini kurikulum 2013 direvisi menjadi Kurikulum Nasional.

\section{KESIMPULAN}

Berdasarkan pengamatan selama pelaksanaan PPM berlangsung, maka dapat disimpulkan:

a. Peserta pelatihan guru-guru Fisika SMA/MA di DIY meningkat keterampilan dalam memilih dan menyusun instrumen penilaian keterampilan dengan pengamatan dan tes.

b. Peserta pelatihan guru-guru Fisika SMA/MA di DIY meningkat keterampilan dalam menyusun pedoman penskoran.

Berdasarkan pengamatan selama pelaksanaan PPM berlangsung, maka dapat disarankan kepada pihak terkait, bahwa:

a. Diperlukan pelatihan lanjutan guru-guru Fisika SMA/MA di DIY dalam menyusun berbagai ragam penilaian pembelajaran Fisika.

b. Diperlukan penataran yang lebih mendalam untuk mendalami pembelajaran Fisika menurut kurikulum 2013 terevisi.

\section{UCAPAN TERIMA KASIH}

Ucapan terima kasih diberikan kepada FMIPA dan ketua MGMP Fisika SMA/MA di Yogyakarta.

\section{PUSTAKA}

Anna Poedjiadi. (2005). Pendidikan Sains dan Pembangunan Moral Bangsa. Bandung: yayasan Cendrawasih

BSNP. (2013). Kompetensi Inti dan kompetensi dasar mata pelajaran Fisika untuk SMA dan MA. Jakarta: BSNP-Depdiknas.

Edi Istiyono, Mardapi, D, \& Suparno (2014). Pengembangan Tes Kemampuan Berpikir Tingkat Tinggi Fisika (PysTHOTS) Peserta Didik SMA. Jurnal Penelitian dan Evaluasi Pendidikan, Tahun 18, Nomor 1, 2014, Halaman 1-12. ISSN 1410-4725 (Cetak) dan ISSN 2338061 (Online)

Hewitt, P.G. (2007).Conceptual Integrated Science. Pearson Education: USA

Lorber, MZ. \& Pierce, W.D. (1990). Objectives, Methods and Evaluation for Secondary Teaching (Third Edition). New Jersey: Prentice-Hall, Inc. 